\title{
Development and Quality Evaluation of Jamun Seed Powder Fortified Biscuit Using Finger Millet
}

\section{Kalse SB*, Swami SB, Sawant AA and Thakor NJ}

Department of Agricultural Process Engineering, College of Agricultural Engineering and Technology, Dr. BS Konkan Krishi Vidyapeeth, Ratnagir, India

\begin{abstract}
Jamun seed are popular among alternative medicine systems to control different ailments such as diabetes, cardio-vascular and gastro-intestinal disorders. Owing to such attributes, the most important aspect of this study to develop jamun seed powder fortified biscuits have been commercialized to meet these purposes. Efforts were made to prepare biscuits having different combinations of Maida (M), finger millet (FM) and jamun seed powder (JSP) were prepared by mixing them in different proportions viz., $\mathrm{T}_{1}-87 \%+10 \%+3 \%, \mathrm{~T}_{2}-84 \%+10 \%+6 \%, \mathrm{~T}_{3}-81 \%+10 \%+9 \%, \mathrm{~T}_{4}-78 \%+10 \%+12 \%$. The biscuits were baked in a thermally controlled oven at temperature of $170^{\circ} \mathrm{C}$ for $20 \mathrm{~min}$. The prepared biscuits were subjected to textural analysis and compared with the control biscuit containing $100 \%$ maida flour.
\end{abstract}

The physical and textural properties of biscuits made by various blending were determined. The qualities of the product were determined with the help sensory evaluation. In sensory analysis treatment $T_{3}(81 \%$ maida $+9 \%$ jamun seed powder $+10 \%$ finger millet flour) secured maximum score for colour, taste, flavour and acceptability. Therefore, treatment $T_{3}$ was more acceptable so it was optimised treatment than others.

Keywords: Jamun seed power; Biscuit; Texture analysis; Diabetes

\section{Introduction}

Biscuit is a term used for a variety of baked, commonly flour-based food products. Indian Biscuits Industry is the largest among all the food industries and has a turnover of around Rs. 3000 crores. India is known to be the second largest manufacturer of biscuits, the first being USA. Biscuits were assumed as sick-man's diet in earlier days. Now, it has become one of the most loved fast food product for every age group. Biscuits are easy to carry, tasty to eat, cholesterol free and reasonable at cost.

Jamun seed powder has been used for centuries as a natural form for balancing the healthy blood sugar level. It is a very delicious, detoxifying herb which has properties that helps to maintain natural urination and sweating. It also acts as liver stimulant, digestive, coolant and a blood Purifier. Jamun seeds contain a glycoside, named Jamboline which helps in the maintenance of glucose levels as in the normal limits.

Finger millet (Eleusine coracana L.) is one of the important millet grown extensively in various regions of India and Africa. Regarding protein $(6 \%$ to $8 \%)$ and fat $(1 \%$ to $2 \%)$ it is comparable to rice and with respect to mineral and micronutrient contents it is superior to rice and wheat. Nutritionally; it has high content of calcium $(344 \mathrm{mg} / 100 \mathrm{~g})$, dietary fiber ( $15 \%$ to $20 \%)$ and phenolic compounds $(0.3 \%$ to $3 \%)$. This minor millet contains important amino acids viz isoleucine, leucine, methionine and phenyl alanine which are deficient in other starchy meals. It is also known for several health benefits such as antidiabetic, anti-tumerogenic, atherosclerogenic effects, antioxidant, which are mainly attributed due to its polyphenol and dietary fibre contents. Being indigenous minor millet it is used in the preparation of various foods both in natural and malted forms. Grains of this millet are converted into flours for preparation of products like porridge, puddings, pancakes, biscuits, roti, bread, noodles, and other snacks. Besides this it is also used as a nourishing food for infants when malted and is regarded as wholesome food for diabetic's patients. Finger millet being staple food in different parts of India and abroad is promoted as an extremely healthy food [1].
Jamun seed powder-containing biscuit has been developed and incorporated into the diabetic diet. It has been found to be effective in reducing the postprandial rise in the blood glucose level and in improving glycaemic control [2]. These biscuits can be used for dealing with the symptoms of indigestion. These biscuits can also stimulate the liver functions [3].

Finger millet has the highest calcium content among all the food grains, but it is not highly assimilable. The protein content in millet is very close to that of wheat; both provide about $11 \%$ protein by weight, on a dry matter basis. Ayurvedic text suggests that 1-3 g of jamun seed powder per day is an average dose for the treatment of diabetes [4] The direct consumption of jamun seed powder is uneasy. Therefore, this work has been undertaken to develop the biscuit so that diabetic people will consume it easily and get recommended dose of jamun seed powder.

\section{Materials and Methods}

\section{Processing of raw material}

The pulp and seed of jamun fruit was separated by pulper. Then the seed washed in water and dried in tray dryer at $60^{\circ} \mathrm{C}$ for 48 hours still complete drying and ground the seed in pulveriser to fine powder of average particle size $0.58 \mathrm{~mm}$. Milling of wheat and finger millet was done to obtain fine flour with help of attrition mill. The proposed research was carried out in the bakery training centre, Department of

*Corresponding author: Kalse SB, Department of Agricultural Process Engineering, College of Agricultural Engineering and Technology, Dr. BS Konkan Krishi Vidyapeeth, Dapoli, Ratnagir, India, Tel: +91-9561144876; E-mail: sandeep.kalse@gmail.com

Received October 17, 2016; Accepted November 03, 2016; Published Novembe 09, 2016

Citation: Kalse SB, Swami SB, Sawant AA, Thakor NJ (2016) Development and Quality Evaluation of Jamun Seed Powder Fortified Biscuit Using Finger Millet. J Food Process Technol 7: 633. doi: 10.4172/2157-7110.1000633

Copyright: ( $) 2016$ Kalse SB, et al. This is an open-access article distributed unde the terms of the Creative Commons Attribution License, which permits unrestricted use, distribution, and reproduction in any medium, provided the original author and source are credited. 
Agricultural Process Engineering, College of Agricultural Engineering and Technology, Dr. Balasaheb Sawant Konkan Krishi Vidhyapeth, Dapoli.

\section{Treatment details}
a. Control - $100 \%(\mathrm{M})$.
b. $\mathrm{T}_{1}-87 \%(\mathrm{M})+10 \%(\mathrm{FM})+3 \%(\mathrm{JSP})$.
c. $\mathrm{T}_{2}-84 \%(\mathrm{M})+10 \%(\mathrm{FM})+6 \%(\mathrm{JSP})$.
d. $\mathrm{T}_{3}-81 \%(\mathrm{M})+10 \%(\mathrm{FM})+9 \%(\mathrm{JSP})$.
e. $\mathrm{T}_{4}-78 \%(\mathrm{M})+10 \%(\mathrm{FM})+12 \%(\mathrm{JSP})$.

\section{Process for preparation of biscuit}

The biscuits were prepared by mixing of ingredients like maida, finger millet (10\%) and jamun seed powder $(3 \%, 6 \%, 9 \%$, and $12 \%)$, salt, sugar etc. were put together for dough formation (Table 1). The dough was kept for resting for 10 minutes. The sheet of appropriate thickness was prepared with the help of wooden roller (bellon). The prepared sheet was cut by using mould (rhomboidal shape). The cutting part of sheet was kept in convective oven as shown in Figure 1 at $170^{\circ} \mathrm{C}$ for 20 $\mathrm{min}$. for baking. After completion of baking the biscuits were allowed to cool at room temperature $\left(26 \pm 2^{\circ} \mathrm{C}\right)$ for 1 hour.

The ingredients required for the preparation of Jamun seed powder fortified biscuit by using finger millet for different compositions are as follow.

\section{Results and Discussion}

The biscuits were prepared by making different proportion of jamun seed powder of average particle size $0.58 \mathrm{~mm}$. The standard procedure was used for preparation of biscuits as described in Figure 1. The maida, finger millet and jamun seed powder and other ingredients were taken as mentioned in Table 1. Then the Physical properties, calorific value and Textural properties was measured. The results obtained are as follows.

\section{Physical properties of biscuit}

The biscuits were prepared with help of mould which is having rhomboidal shape. All the biscuits were prepared with the help of same mould hence the shape of the all the biscuits were same i.e. rhomboidal shape. The physical properties measured for all treatments are shown in Table 2 .

All the biscuits were prepared with the help of same mould so there was minute difference for the length and breadth for all the treatments. The length of $\mathrm{T}_{1}, \mathrm{~T}_{2}$ and $\mathrm{T}_{4}$ was $7.3 \pm 0.05$ and for $\mathrm{T} 3$ it was $7.2 \pm 0.05$ $\mathrm{cm}$. The breadth for treatment $\mathrm{T}_{1}$ was $3.6 \pm 0.057 \mathrm{~cm}$ and that for treatment $\mathrm{T}_{2}, \mathrm{~T}_{3}$ and $\mathrm{T}_{4}$ was $3.5 \pm 0.057 \mathrm{~cm}$. Thickness for the treatment $\mathrm{T}_{1}, \mathrm{~T}_{2}, \mathrm{~T}_{3}$ and $\mathrm{T}_{4}$ were $0.70 \pm 0.009,0.75 \pm 0.008,0.77 \pm 0.008,0.76$ $\pm 0.007 \mathrm{~mm}$ respectively. The unit weight for the treatment $\mathrm{T}_{1} \mathrm{~T}_{2}, \mathrm{~T}_{3}$ and $\mathrm{T}_{4}$ were $9.325 \pm 0.09,9.356 \pm 0.07,9.414 \pm 0.06,9.420 \pm 0.057 \mathrm{~cm}$ respectively. The density for the treatment $\mathrm{T}_{1}, \mathrm{~T}_{2}, \mathrm{~T}_{3}$ and $\mathrm{T}_{4}$ were 0.345 $\pm 0.0071,0.345 \pm 0.0069,0.347 \pm 0.0068,0.346 \pm 0.007 \mathrm{~cm}$ respectively.

\section{Textural analysis}

The texture of biscuit was measure with QTS Texture Analyser made by M/s. Brookfield Engineering Labs, Inc., USA. The experiment was repeated for three times for its replication and average peak force (g) be reported. In the test, the probe was allowed to penetrate in the specimen up to $3 \mathrm{~mm}$ at a constant speed of $0.5 \mathrm{~mm} / \mathrm{sec}$. Figure 2 shows the mean values of hardness of biscuit samples having different proportions of jamun seed powder as calculated in various experiments. From Figure 3, it was found that maximum hardness was obtained in treatment $T_{2}$ whereas minimum hardness was obtained in treatment $\mathrm{T}_{1}$. The hardness values obtained for the biscuits of various blends were in the range of 468.33 to $4535 \mathrm{~g}$.

\section{Calorific value}

The Calorific value of the developed biscuits was determined by using the Bomb Calorimeter (ASTM D271-70) [5]. Table 3 shows the results of the calorific value of the developed biscuits. The calorific value of all type of biscuits (experimental samples) varied between 402.23 to $482.68 \mathrm{kcal} / 100 \mathrm{~g}$. The calorific value of the treatment $\mathrm{T}_{3}$ was found more i.e. $482.68 \mathrm{kcal} / 100 \mathrm{~g}$ followed by the treatment $\mathrm{T}_{2}$, i.e. $453.426 \mathrm{kcal} / 100 \mathrm{~g}$.

\section{Sensory analysis}

Sensory analysis has been carried out in NAIP laboratory of Department. of Agricultural Process Engineering and Technology, CAET, Dapoli. Product of different treatments was analyzed by different subjects in our college faculty and students. They were

\begin{tabular}{|c|c|c|c|c|}
\hline Ingredients (g) & $\mathbf{T}_{\mathbf{1}}$ & $\mathbf{T}_{\mathbf{2}}$ & $\mathbf{T}_{\mathbf{3}}$ & $\mathbf{T}_{\mathbf{4}}$ \\
\hline Maida & 870 & 840 & 810 & 780 \\
\hline Jamun seed powder & 30 & 60 & 90 & 120 \\
\hline Finger millet & 100 & 100 & 100 & 100 \\
\hline Baking powder & 10 & 10 & 10 & 10 \\
\hline Milk powder & 20 & 20 & 20 & 20 \\
\hline Salt & 5 & 5 & 5 & 5 \\
\hline Sugar & 200 & 200 & 200 & 200 \\
\hline Dalda & 250 & 250 & 250 & 250 \\
\hline
\end{tabular}

Table 1: Ingredients required for the preparation of jamun seed powder biscuits (per $1 \mathrm{~kg}$ flour basis).

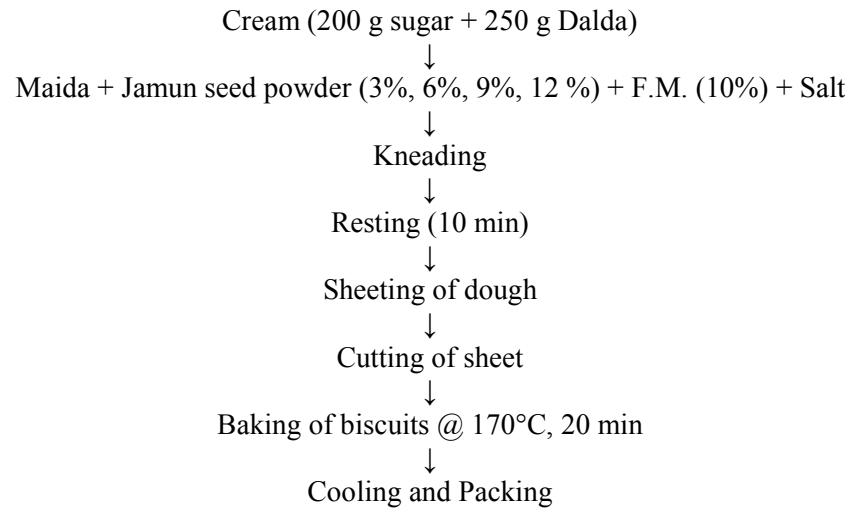

Figure 1: Process flow chart of preparation of jamun seed powder biscuit.

\begin{tabular}{|c|c|c|c|c|c|}
\hline S.no. & Properties & $\mathrm{T}_{1}(3 \% \mathrm{JSP})$ & $\mathrm{T}_{2}(6 \% \mathrm{JSP})$ & $\mathrm{T}_{3}$ (9\% JSP) & $T_{4}(12 \%$ JSP $)$ \\
\hline 1. & Length (cm) & $7.3 \pm 0.05$ & $7.3 \pm 0.05$ & $7.2 \pm 0.05$ & $7.3 \pm 0.05$ \\
\hline 2. & Breadth $(\mathrm{cm})$ & $3.6 \pm 0.057$ & $3.5 \pm 0.057$ & $.5 \pm 0.057$ & $3.5 \pm 0.057$ \\
\hline 3. & $\begin{array}{l}\text { Thickness } \\
\text { (cm) }\end{array}$ & $0.70 \pm$ & $0.75 \pm$ & $0.77=$ & 0.76 \\
\hline 4. & $\begin{array}{l}\text { Unit weight } \\
\text { (g) }\end{array}$ & 9.325 & $9.356 \pm$ & 9.414 & 9.420 \\
\hline 5. & $\begin{array}{l}\text { Density (g/ } \\
\text { cc) }\end{array}$ & $\begin{array}{l}0.345 \pm \\
0.0071\end{array}$ & $\begin{array}{l}0.345 \pm \\
0.0069\end{array}$ & $\begin{array}{l}0.347 \pm \\
0.0068\end{array}$ & $0.346 \pm 0.007$ \\
\hline
\end{tabular}

Table 2: Physical properties of biscuit for different treatment. 


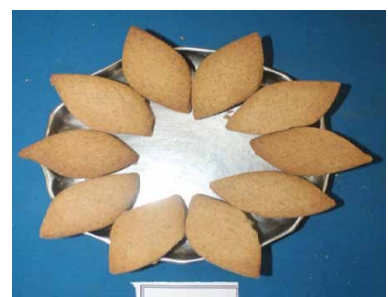

$\mathrm{T}_{1}$

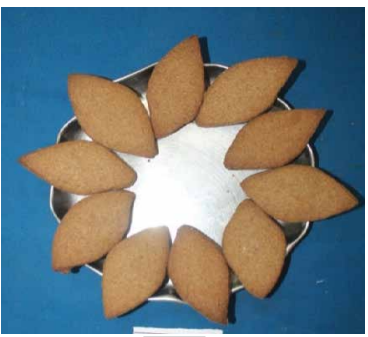

$\mathbf{T}_{3}$

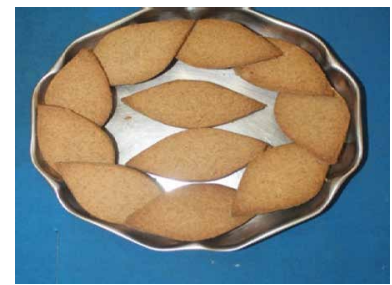

$T_{2}$

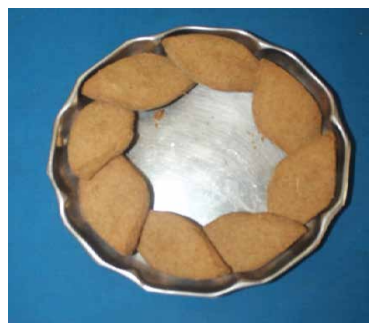

$\mathbf{T}_{4}$
Figure 2: Jamun seed powder biscuits prepared by different treatments.

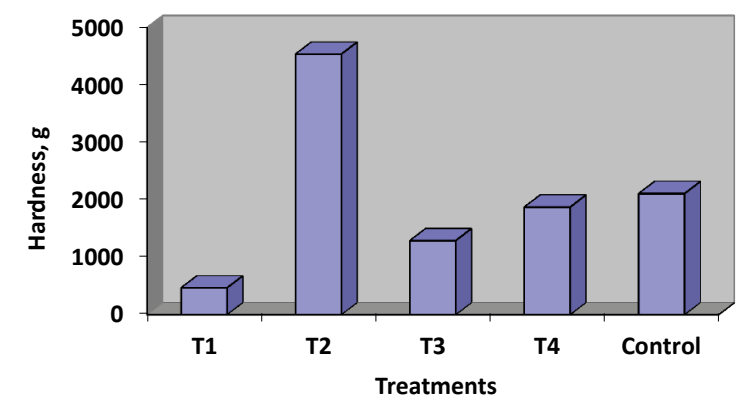

Figure 3: Hardness of different biscuit.

\begin{tabular}{|c|c|}
\hline Treatment & Calorific value (kcal/100g) \\
\hline $\mathrm{T}_{1}$ & 402.23 \\
\hline $\mathrm{T}_{2}$ & 453.426 \\
\hline $\mathrm{T}_{3}$ & 482.68 \\
\hline $\mathrm{T}_{4}$ & 446.18 \\
\hline Control & 409.546 \\
\hline
\end{tabular}

Table 3: Calorific value of developed biscuits.

\begin{tabular}{|c|c|c|c|c|c|}
\hline \multirow{2}{*}{$\begin{array}{c}\text { Sample } \\
\text { Code }\end{array}$} & \multicolumn{5}{|c|}{ Sensory Parameters Score (Out of 9) } \\
\hline & $\begin{array}{l}\text { Colour } \\
\text { (9) }\end{array}$ & $\begin{array}{l}\text { Taste } \\
\text { (9) }\end{array}$ & $\begin{array}{l}\text { Flavour } \\
\text { (9) }\end{array}$ & $\begin{array}{c}\text { Texture } \\
\text { (9) }\end{array}$ & $\begin{array}{c}\text { Acceptability } \\
\text { (9) }\end{array}$ \\
\hline $\mathrm{T}_{1}$ & 7.5 & 8.5 & 7.5 & 7.0 & 7.5 \\
\hline $\mathrm{T}_{2}$ & 7.0 & 7.2 & 7.0 & 6.8 & 7.2 \\
\hline $\mathrm{T}_{3}$ & 8.0 & 7.9 & 8.1 & 7.9 & 7.8 \\
\hline $\mathrm{T}_{4}$ & 4.7 & 6.0 & 6.8 & 5.2 & 7.6 \\
\hline Control & 7.8 & 8.1 & 8.0 & 8.0 & 7.6 \\
\hline
\end{tabular}

Table 4: Results of sensory analysis. provided with standard evaluation sheets based on nine-point hedonic scale by 20 members' consumer test panel for colour, texture, flavour, taste, appearance and overall acceptability for Jamun seed powder based biscuits. From collected data following results were derived as shown in Table 4

The sensory analysis of the developed biscuits was carried out by the 20 panel of judges from the faculty and students of the college. The treatment $\mathrm{T}_{3}(81 \% \mathrm{M}+10 \% \mathrm{FM}+9 \% \mathrm{JSP})$ secured maximum score for colour, taste flavour and acceptability i.e. 8.0, 7.9, 8.1, 7.9 and 7.8 respectively.

\section{Summary and Conclusion}

Jamun seed powder in combination with finger millet and maida were used to prepare biscuit by using traditional creamy method. The results pertaining to standardization of composite flour for biscuit preparation revealed that sensorial quality characteristics of biscuits could be improved with incorporation of maida, finger millet flour and jamun seed powder. The various physical properties i.e. Length, width, thickness, unit weight, density, and calorific value, Textural properties of biscuits were determined.

The following conclusions were drawn from the analysis.

I. The density of Jamun seed powder biscuits was found to be in range of 0.345 to $0.347 \mathrm{~g} / \mathrm{cc}$.

II. The calorific value of all type of biscuits varied between 402.23 to $482.68 \mathrm{kcal} / 100 \mathrm{~g}$. The calorific value of treatment $\mathrm{T}_{3}$ was found more i.e. $482.68 \mathrm{kcal} / 100 \mathrm{~g}$ compared to others.

III. In textural analysis, the hardness values of biscuit $\mathrm{T}_{1}, \mathrm{~T}_{2}, \mathrm{~T}_{3}$ and $\mathrm{T}_{4}$ were $468.33,4535,1291.66$ and 1873.33 g respectively. The treatment $\mathrm{T}_{2}$ has more hardness i.e. $4535 \mathrm{~g}$ and moderate hardness was found in treatment $\mathrm{T}_{3}(81 \% \mathrm{M}+9 \% \mathrm{JSP}+10 \%$ FM).

IV. In sensory analysis treatment $\mathrm{T}_{3}(81 \% \mathrm{M}+9 \% \mathrm{JSP}+10 \%$ FM) secured maximum score for colour, taste, flavour and acceptability. Therefore, treatment $\mathrm{T}_{3}$ was more acceptable so it was optimised treatment than others.

\section{References}

1. Amir G, Jan R, Nayik GA, Prasand K, Kumar P (2014) Significance of finger millet in nutrition, health and value added products: A review. J Environ Sci Comp Sci Eng Technol 3: 1601-1608.

2. Bhargava S (1991) Efficiency of bitter gourd and jamun fruit seed in the treatment of diebetis mellitus. Department of Food and Nutrition, College of Home Science, Udaipur, RAJASTHAN (INDIA).

3. Shorti DS, Kelkar M, Deshmukh VK, Aiman R (1962) Investigation of hypoglycaemic properties of Vinca rosea and Eugenia jambolina. Indian Med 3: 51-62.

4. Swami SB, Nayansingh Thakur J, Patil M, Haladankar P (2012) Jamun (Syzygium cumini L): A review of its food and medicinal uses. Food Nutri Sci 1102

5. ASTM (2006) Laboratory sampling and analysis of coal and coke. ATSM Method D271-70. 